\title{
W trosce o zachowanie pamięci... Działalność popularyzatorska Archiwum Nauki PAN i PAU w latach 2016-2018
}

„Więź z przeszłością musi wynikać - jeśli ma być żywa i bezpośrednia - z kontaktu z oryginałem: słowem czy obrazem"1. Parafrazując to zdanie, można powiedzieć, że podtrzymywanie żywej i bezpośredniej więzi z przeszłością jest w istocie warunkiem koniecznym do zachowania wspólnego dziedzictwa. Podstawą tej relacji będzie zawsze informacja docierająca do jak najszerszego grona odbiorców. Podejmowane przez instytucje inicjatywy z zakresu eksponowania zbiorów nie tylko budują świadomość i kulturę naukową w wymiarze społecznym, ale też skracają dystans i rodzą poczucie współuczestnictwa. Archiwum Nauki Polskiej Akademii Nauk i Polskiej Akademii Umiejętności (dalej: Archiwum Nauki) od lat jest organizatorem bądź współorganizatorem przedsięwzięć popularyzujących naukę, dokonania uczonych w oparciu o własny zasób poprzez wystawy, pokazy, konferencje, publikacje oraz projekty badawcze ${ }^{2}$. Niniejszy tekst stanowi próbę zaprezentowania wybranych działań w tym zakresie z lat 2016-2018. Osoby zainteresowane aktywnością archiwum w innych obszarach odsyłamy do Rocznika Polskiej Akademii Umiejętności

Działalność naukowo-popularyzatorska Archiwum Nauki w ostatnich latach skupiła się na podkreśleniu dwóch historycznych fenomenów: Towarzystwa Naukowego Krakowskiego (1815-1872) oraz zjawiska społecznego ofiarodawstwa na rzecz Akademii Umiejętności (dalej: AU) i Polskiej Akademii Umiejętności (dalej: PAU), pokazując konsekwentnie, jak szeroko rozumiana idea nauki przez stulecia łączyła ludzi. Co więcej granice nie stanowiły przeszkody dla tej uniwersalnej wartości, która jednoczyła badaczy różnych narodowości i pokoleń. Nic więc dziwnego, że wzajemne kontakty oraz podróże uczonych stały się tematem archiwalnych wystaw. Inspiracji do zorganizowania kolejnych ekspozycji dostarczyły również bieżące wydarzenia, takie jak: 100. rocznica odzyskania niepodległości,

${ }^{1}$ Piotr Hübner, Od Towarzystwa Naukowego Krakowskiego do Polskiej Akademii Umiejętności. Refleksje jubileuszowe Mieczysława Offmańskiego, Tadeusza Sinki, Stanisława Wróblewskiego, Stanisława Kutrzeby, „Studia i Materiały do Dziejów Polskiej Akademii Umiejętności” 2002, t. 1, s. 7.

${ }^{2}$ Zob. np. Rita Majkowska, Ocalone od niepamięci, pokazane światu..., [w:] Małgorzata Mrówka, Marcin Maciuk, Ocalone od niepamięci... Co kryją archiwa osobiste uczonych i twórców? W 10. rocznice powołania Archiwum Nauki PAN i PAU w Krakowie, Kraków 2012, s. 7-14; Tomasz Skrzyński, Wystawy w Archiwum Nauki PAN i PAU, „Archiwista Polski” 2005, nr 2 (38), s. 39-46; Sprawozdania z wernisaży, omówienia wystaw, konferencji ukazują się również na łamach „Krakowskiego Rocznika Archiwalnego”.

${ }^{3}$ Rita Majkowska, Z działalności Archiwum Nauki PAN i PAU w 2016 roku, „Rocznik Polskiej Akademii Umiejętności” (dalej: „Rocznik PAU”), R. 2016/2017, s. 141-145; eadem, Z działalności Archiwum Nauki PAN i PAU w 2017 roku, „Rocznik PAU”, R. 2017, s. 107-113; Adam Górski, Sprawozdanie z działalności Archiwum Nauki PAN i PAU w 2018 roku, „Rocznik PAU”, R. 2018, s. $153-155$. 
60-lecie istnienia Oddziału Polskiej Akademii Nauk (dalej: PAN) w Krakowie czy V Kongres Polskich Towarzystw Naukowych w Świecie.

Specyfika instytucji funkcjonującej jako sprofilowane archiwum naukowe powoduje, że jego oferta spotyka się głównie z zainteresowaniem ze strony środowisk akademickich: pracowników naukowych i studentów. Archiwum pozostaje jednak miejscem otwartym dla wszystkich pasjonatów oraz miłośników wiedzy.

Za najważniejsze wydarzenie 2018 r. należy uznać wpisanie materiałów Towarzystwa Naukowego Krakowskiego oraz najstarszych dokumentów PAU do chwili odzyskania przez Polskę niepodległości w 1918 r. na Polską Listę Krajową Programu UNESCO Pamięć Świata. W III edycji uhonorowano łącznie 21 obiektów. Uroczystość wręczenia certyfikatów odbyła się 28 września w Belwederze. Towarzyszyła jej dwudniowa wystawa „Pamięć Polski - Dokumenty Niepodległej” (29-30 września) ${ }^{4}$, którą odwiedziło blisko 1000 osób. Symboliczny rok dokonania wpisu podkreśla wyjątkowość stowarzyszenia, które poprzez badania, pionierskie inicjatywy uczonych oraz kontakty zewnętrzne kładło podwaliny pod rozbudowę przyszłego państwa polskiego. Patrząc przez pryzmat archiwalnych starań, zintensyfikowanych w 2015 r. w związku z obchodami jubileuszu 200-lecia powołania Towarzystwa (wystawy, wirtualne spacery, konferencja w dniach 9-10 grudnia, konkurs dla młodzieży, okolicznościowa strona internetowa i in. $)^{5}$ - wpis był ukoronowaniem działań ugruntowujących pozycję tego zespołu akt jako cennego, aczkolwiek długo niedocenianego źródła ${ }^{6}$.

Warto nadmienić, że jako pokłosie wspomnianej wyżej konferencji jubileuszowej ukazała się w 2016 r. publikacja podsumowująca rolę Towarzystwa w życiu naukowym Krakowa i ziem polskich ${ }^{7}$. Jego przekształcenie w AU (1872), a później PAU (1919), pozwoliło na konsekwentne rozwinięcie działalności organizacyjno-naukowej. Podkreślały to wystawy: „Wznosząc gmach narodowej wiedzy. 200. rocznica powołania Towarzystwa Naukowego Krakowskiego" (9 grudnia 2015 - 30 marca 2016 r.) oraz prezentowana do końca lutego 2016 r. w formie posterów w gmachu PAU - „Gdy jedna myśl rodzi drugą. Towarzystwo Naukowe staje się Akademią Umiejętności". To swoistego rodzaju continuum stanowi dzi-

${ }^{4}$ Pamięć Polski. Dokumenty Niepodległej. Wystawa III edycji Polskiej Listy Krajowej Programu UNESCO Pamięć Świata, oprac. Tomasz Mrożek, Grzegorz Mędykowski, Katarzyna Szewczyk-Rodzik, Warszawa 2018.

${ }^{5}$ Więcej na temat inicjatyw towarzyszących jubileuszowi, zob. Marcin Maciuk, Małgorzata Mrówka, Wokót 200. rocznicy powołania Towarzystwa Naukowego Krakowskiego (1815-1872), „Krakowski Rocznik Archiwalny” 2016, t. 22, s. 240-242.

${ }^{6}$ Danuta Rederowa, Krystyna Stachowska, Ośrodek Naukowy Krakowski w świetle materiałów Towarzystwa Naukowego Krakowskiego 1841-1871. Wybór źródet, „Rocznik Biblioteki Polskiej Akademii Nauk w Krakowie” 1956, R. 2, s. 12: „Materiały Towarzystwa Naukowego Krakowskiego, dotąd nie publikowane, znajdujące się w Oddziale Archiwum PAN w Krakowie, są źródłem do poznania początków znakomitego rozwoju ośrodka naukowego krakowskiego w drugiej połowie XIX w. Rola i wkład Towarzystwa w rozkwit nauki jak dotąd nie są doceniane. Zwrócenie uwagi badaczom historii nauki na wielkiej wagi materiały Towarzystwa niewątpliwie przyczyni się do pełniejszego poznania tego okresu w dziejach nauki polskiej”.

7 Towarzystwo Naukowe Krakowskie w 200-lecie założenia (1815-2015). Materiaty konferencji naukowej 9-10 grudnia 2015, red. Jerzy Wyrozumski, Kraków 2016. 
siaj bezcenne świadectwo dziejów nauki polskiej, uchwycone jednym zdaniem przez prof. Piotra Hübnera: „Tradycja jest drogą prowadzącą poprzez historię"

Współczesność otwiera jednak nowe możliwości. Digitalizacja materiałów i upublicznienie pierwszej części inwentarza elektronicznego zespołu akt Towarzystwa Naukowego Krakowskiego w grudniu 2016 r. (8 600 skanów) zapewniły do nich dostęp szerszemu gronu badaczy i pasjonatów9. Kontynuacja prac (w 2017 r. wykonano 11885 skanów) pozwoli na udostępnienie online całego, liczącego ok. 2,6 mb, zespołu, zachowanego w stanie niemal kompletnym ${ }^{10}$.

Wyeksponowanie roli Towarzystwa i jego kontynuatorki PAU, podkreślenie roli nauki jako uniwersalnej wartości uprawianej dla dobra ogółu wprowadza nas w obręb problematyki naukowego mecenatu i darczyństwa, któremu poświęcono dwie wystawy: „Łącząc miłość nauki z miłością Ojczyzny. Ofiarodawstwo na rzecz Polskiej Akademii Umiejętności” (18 listopada 2016 - 30 marca 2017 r.) oraz „Z myślą o przyszłości nauki i Ojczyzny. Ofiarodawstwo na rzecz Polskiej Akademii Umiejętności” (16 listopada 2017 - 23 marca 2018 r.), połączonej z konferencją naukową zorganizowaną we współpracy z PAU pt. „Mecenasi i darczyńcy w dziejach nauki polskiej. AU i PAU w kręgu społecznej troski" (16-17 listopada 2017 r.). Sesji towarzyszyła również wystawa posterowa oraz audycje radiowe ${ }^{11}$.

Celem konferencji i ekspozycji było zaprezentowanie wybranych zapisów, legatów egzemplifikujących rozmiar oraz charakter zjawiska, a także przybliżenie sylwetek często zapomnianych donatorów. Naród rozbity politycznie koncentrował się wokół instytucji naukowych. Swoje poparcie dla Akademii jako nośnika polskości manifestował poprzez dary materialne i finansowe. Fundament ten pozwolił PAU na niezależność w okresie międzywojennym oraz umożliwił rozwój wielu inicjatyw badawczych, wydawniczych, stypendialnych. Owo zaufanie leżało również u podstaw budowania etosu obywatelskiego. Niektóre z fundacji wpisały się już na stałe w kulturalny obraz Krakowa, jak nagrody im. Mikołaja Kopernika czy Erazma i Anny Jerzmanowskich. Warto zaznaczyć, że prace nad kartoteką ofiarodawców Archiwum Nauki podjęło wiele lat wcześniej. Imponująca liczba ponad 400 darczyńców o różnym statusie społecznym i materialnym podkreśla skalę zjawiska ${ }^{12}$. Wielowymiarowy i złożony charakter problemu pozwolił organizatorom jedynie na zarysowanie pewnych kwestii. Niemniej jednak trudno nie zgodzić się z podniesionym postula-

\footnotetext{
${ }^{8}$ P. Hübner, Od Towarzystwa Naukowego Krakowskiego..., s. 245.

${ }^{9}$ Rita Majkowska, Droga do digitalizacji akt Towarzystwa Naukowego Krakowskiego w Archiwum Nauki PAN i PAU, „Rocznik Biblioteki Naukowej PAU i PAN w Krakowie” 2015, R. 60, s. 69-73.

${ }^{10}$ Zob. inwentarz.tnk.krakow.pl (odczyt: 22.03.2019).

${ }^{11}$ Zob.http://pau.krakow.pl/index.php/en/aktualnosci-2/1357-konferencja-mecenasi-i-darczyncyw-dziejach-nauki-polskiej (odczyt: 25.03.2019).

${ }^{12}$ Zob. Marta Płatek (Tylka), Źródła i formy finansowania działalności Polskiej Akademii Umiejętności w latach 1873-1952, „Rocznik PAU”, R. 1994/1995, s. 179-188; Marta Tylka, Wykaz ofiarodawców na cele ogólne Polskiej Akademii Umiejętności, [w:] Marcin Maciuk, Łącząc miłość nauki z miłością Ojczyzny. Ofiarodawstwo na rzecz Polskiej Akademii Umiejętności, Kraków 2016, s. 107-137; Marta Tylka, Wykaz ofiarodawców, osób i instytucji na cele szczegółowe Polskiej Akademii Umiejętności, [w:] Marcin Maciuk, Z myśla o przyszłości nauki i Ojczyzny. Ofiarodawstwo na rzecz Polskiej Akademii Umiejętności, Kraków 2017, s. 127-148.
} 
tem: „Chcielibyśmy, aby ów fenomen znalazł w niedalekiej przyszłości nie tylko należyte zainteresowanie historyków i nie tylko został historycznie udokumentowany w skali całej Polski i w środowiskach polskiej diaspory, ale by doczekał się także, jako problem par excellence historyczny, również socjologicznej analizy i socjologicznego opisu"13.

Działalność stypendialna, rozwijana dzięki prywatnym zapisom, umożliwiała również uczonym pobyty w zagranicznych ośrodkach badawczych. Kontakty oraz wymiana myśli były bramą pozwalającą przejść przez granice w XX w. Przypominały o idei trwania nauki w duchu kontynuacji współpracy oraz ewoluowały w stronę trwalszych relacji - przyjaźni naukowych. Ta prawda stała się okazją do pochwalenia się zbiorami w ramach wystawy „Nauka ponad granicami. Z zagranicznych kontaktów uczonych polskich w XX wieku” (17 czerwca - 28 października 2016 r.), będącej szkicem bogatej działalności polskich badaczy na arenie międzynarodowej. Przygotowana została na podstawie materiałów ze spuścizn: historyka Henryka Batowskiego (1907-1999), filologa-romanisty Zygmunta Czernego (1888-1975), geologa Walerego Goetla (1889-1972), zoologa Zygmunta Grodzińskiego (1896-1982) czy fizyka Henryka Niewodniczańskiego (1900-1968).

Nawiązywała do niej ekspozycja „Polscy uczeni w świecie. Wymiana inspiracji i wiedzy w kontaktach uczonych Europy Środkowej” (16 października - 3 listopada 2017 r.), towarzysząca V Kongresowi Polskich Towarzystw Naukowych w Świecie - „Inteligencja polska w świecie" (17-21 października), zorganizowanemu przez PAU. Przedstawione formy kontaktów z nauką środkowoeuropejską (konferencje, kongresy, zjazdy) stanowiły tylko wycinek zagadnienia. Prezentowana korespondencja pozwalała wczuć się w ówczesny dyskurs naukowy. Fotografie przenosiły w realne miejsca spotkań, a dyplomy podkreślały wzajemny szacunek i uznanie badaczy. Wykorzystano materiały ze spuścizn m.in. orientalistów Tadeusza Kowalskiego (1889-1948) oraz Władysława Kotwicza (1872-1944), historyka Władysława Semkowicza (1878-1949), prawnika Adama Vetulaniego (1901-1976) czy językoznawcy Jana Rozwadowskiego (1867-1935) ${ }^{14}$.

Temat współpracy zagranicznej pojawiał się już wielokrotnie na wystawach prezentowanych w ramach cyklu „W służbie nauki”, przypominającego sylwetki zasłużonych uczonych. Tym samym tytułem opatrzona jest seria wydawnicza będąca efektem współdziałania Archiwum Nauki i PAU, prezentująca materiały z organizowanych posiedzeń i sympozjów $^{15}$. W 2018 r. wydano dwa tomy poświęcone profesorom, którzy na trwałe wpisali się W obraz krakowskiego ośrodka naukowego ${ }^{16}$.

Zainteresowaniem cieszyły się również wystawy posterowe zamieszczone przy Gabinecie Prezesa PAN w Pałacu Kultury i Nauki w Warszawie, np. „Przeżywamy straszne czasy... Wielka Wojna w pamiętnikach Ludmiły Wróblewskiej” (24 sierpnia 2015 - 31 maja

${ }^{13}$ Jerzy Wyrozumski, By pamięć trwała..., [w:] M. Maciuk, Z myśla o przyszłości nauki i Ojczyzny..., s. 7.

${ }^{14}$ Zob. Ewa Dziurzyńska, Polscy uczeni w świecie. Wymiana inspiracji i wiedzy w kontaktach uczonych Europy Środkowej, Kraków 2017.

${ }^{15}$ Zob. R. Majkowska, Ocalone od niepamięci..., s. 10.

${ }^{16}$ Roman Dyboski (1883-1945). Władysław Tarnawski (1885-1951). Materiały z posiedzenia naukowego w dniu 18 listopada 2011 r., red. Julian Dybiec, W Służbie Nauki nr 28, Kraków 2018; Emanuel Mateusz Rostworowski (1923-1989). Materiały z posiedzenia naukowego w dniu 8 października 2014 r., red. Julian Dybiec, W Służbie Nauki nr 29, Kraków 2018. 
2016 r.), będąca wyrazem hołdu dla świadków Wielkiej Wojny, oparta na wspomnieniach z niepublikowanego dziennika znajdującego się w spuściźnie historyka Tadeusza Dubieckiego (1885-1972), zilustrowana archiwaliami malarza Kazimierza Mitery (18971936) czy językoznawcy Zenona Klemensiewicza (1891-1969). Kolejna ekspozycja „Na falach Nilu. Z podróży Walerego Goetla do Afryki” (1 czerwca 2016 - styczeń 2018 r.) nawiązywała do jego uczestnictwa w XI Kongresie Geograficznym w Kairze (1925) oraz XV Międzynarodowym Kongresie Geologicznym w Pretorii (1929). Po zakończeniu obrad wraz z Jerzym Lothem (1880-1967) przemierzył wzdłuż kontynent. Podczas tej wyprawy miał okazję zobaczyć źródła Nilu, które jeszcze kilkadziesiąt lat wcześniej były zagadką przyciągającą podróżników. Archiwum Nauki nie pierwszy raz sięgnęło po materiały z tego zespołu. W 2005 r. zainicjowano nimi cykl „Podróże uczonych”"17. Wykorzystane zdjęcia to zaledwie ułamek znajdującego się w spuściźnie niezwykle cennego zbioru fotografii z niemal każdego zakątka świata.

Jako osobną w tej grupie ze względu na uroczysty charakter, co pragniemy podkreślić, traktować można zamieszczoną przy Gabinecie Prezesa PAN w styczniu 2018 r. okolicznościową ekspozycję towarzyszącą Sesji Jubileuszowej Zgromadzenia Ogólnego Członków PAN Oddziału w Krakowie z okazji 60-lecia działalności, która odbyła się 14 listopada 2017 r. w Librarii Collegium Maius Uniwersytetu Jagiellońskiego (dalej: UJ).

Z ogromnym entuzjazmem spotkała się wystawa „Orient bliski i daleki” (15 czerwca - 23 października 2018 r.), której finisaż towarzyszył międzynarodowej konferencji naukowej ,7th International Conference of Oriental Studies: Collections of Texts and Artefacts" (22-24 października). Przygotowana została w oparciu o materiały ze spuścizn orientalistów: Tadeusza Kowalskiego (1889-1948), Romana Stopy (1895-1995), Władysława Kotwicza (1872-1944), Bronisława Piłsudskiego (1866-1918), Mariana (19081955) i Tadeusza Lewickich (1906-1992), Zygmunta Abrahamowicza (1923-1990) oraz dzięki uprzejmości osób prywatnych. Była ona okazją „,do wędrówki” śladami uczonych po Afryce, Mongolii, Sachalinie czy stepach Anatolii. Wśród obiektów można było zobaczyć m.in. miniaturowe wydanie Koranu, notatnik z zapisem nutowym i słowami pieśni ludów afrykańskich z okresu międzywojennego, kopię fragmentu ilustrowanego rękopisu mongolskiego „Historia Molom tojna obdarzonego mocami magicznymi” z początku XX w. czy jeden z naszych najstarszych obiektów, rękopis zapisów Sądu Duchownego Ormian miasta Lwowa za lata $1625-1630^{18}$. Bogactwo tej wystawy to kwintesencja Archiwum Nauki, którego unikatowy charakter tkwi w różnorodności gromadzonych materiałów.

W 2018 r. przygotowano również wystawę „Niepodległej... 100. rocznica odzyskania niepodległości 1918-2018” (16 listopada 2018 - 15 marca 2019 r.), która była merytoryczną kontynuatorką prezentowanej w 2014 r. ekspozycji „Odłamki pamięci o Wielkiej Wojnie. Tym, którym cześć i miłość winniśmy w darze”. W symboliczny sposób spięły one klamrą początek i koniec militarnych zmagań, otwierając przestrzeń do refleksji. Podkreślając wartość tej skondensowanej lekcji historii, warto nadmienić, że choć II wojna światowa rysuje

${ }^{17}$ Bernadeta Wilk, ,Podróże uczonych....”- wystawy Archiwum Nauki PAN i PAU w Krakowie, prezentowane w Pałacu Kultury i Nauki w Warszawie, „Krakowski Rocznik Archiwalny” 2008, t. 14 , s. 293-294.

${ }^{18}$ Zob. Ewa Dziurzyńska, Orient bliski i daleki, Kraków 2018 (wystawie towarzyszyła również wersja anglojęzyczna publikacji). 
się mocno w powszechnym odbiorze, to: „Pierwsza zachowuje jednak w naszej zbiorowej pamięci znamię szczególne, bo po 123 latach niewoli przyniosła Polsce niepodległość. Była tym wymodlonym od czasów Ksiag narodu i pielgrzymstwa polskiego Adama Mickiewicza konfliktem powszechnym, który miał połączonych Świętym Przymierzem zaborców Polski postawić przeciwko sobie. Miała więc ta wojna swoje polskie sacrum [...]"19. Prezentowane na wystawie „Niepodległej...” archiwalia ujęto w dwie części obrazujące walkę zbrojną o utrzymanie granic i zachowanie całości terytorium odradzającego się kraju oraz prowadzone równolegle zabiegi na polu dyplomatycznym na rzecz formowania się państwowości polskiej. Wykorzystano materiały ze spuścizn m.in. polonistki Mieczysławy Mitery-Dobrowolskiej (1900-1992), historyka sztuki Jerzego Dobrzyckiego (1900-1972), językoznawcy Kazimierza Nitscha (1874-1958), filozofa Wincentego Lutosławskiego (1863-1954) ${ }^{20}$.

W duchu symbiozy nauki i sztuki organizowane są wystawy we współpracy z Biblioteką Naukową PAU i PAN: „Krzysztof Skórczewski Miedzioryty. Dar dla Gabinetu Rycin PAU” (16 maja - 6 czerwca 2016 r.), „Bogna Krasnodębska-Gardowska (19001986). Grafiki z kolekcji Gabinetu Rycin PAU” (8 maja - 30 czerwca 2017 r.) oraz „Seria oryginalnych grafik artystów polskich w opracowaniu Aliny Kalczyńskiej 1984-2014" (9 maja - 4 czerwca 2018 r.). Miłośników ekslibrisów zaprosiliśmy w 2017 r. na ekspozycję: „Ekslibrisy i małe grafiki Krzysztofy Lachtary” (16-29 września), zorganizowaną z krakowską Galerią Ekslibrisu.

Wystawom towarzyszą okolicznościowe publikacje, foldery, spacery wirtualne i prezentacje multimedialne poszerzające kontekst poruszanej tematyki. Informacje o wydarzeniach zamieszczane są na stronie internetowej oraz w „PAUzie Akademickiej”. Grupy zorganizowane korzystają z możliwości oprowadzania kuratorskiego.

Istotnym elementem działalności popularyzatorskiej są również warsztaty i pokazy. Instytucja adresuje swoją ofertę edukacyjną do młodzieży, studentów i innych grup zainteresowanych zbiorami czy szeroko pojętą tematyką spuścizn. Udział w spotkaniach biorą przede wszystkim osoby z uczelni krakowskich, ale wśród gości w omawianym czasie znaleźli się także studenci oraz wykładowcy z Daemen College w Amherst w stanie Nowy York (22 czerwca 2016 r.) czy uczestnicy konferencji zorganizowanej przez Instytut Historii UJ - „Intellectuals and the First World War: a Central European Perspective” z Austrii, Chorwacji, Czech, Niemiec, Ukrainy oraz USA (21 października 2016 r.). Pokazy adresowane do specjalistów, np. Stowarzyszenia Archiwistów Polskich, są okazją do dyskusji i wymiany doświadczeń.

W celu przybliżenia sylwetek uczonych, uatrakcyjnienia pokazów i uprzystępnienia wydarzeń dąży się do jak największego zróżnicowania obiektów. Obok dokumentacji aktowej prezentowana jest dokumentacja nieaktowa, a nawet przedmioty codziennego użytku czy związane z działalnością naukowo-zawodową, jak np. preparaty mikroskopowe do układu chłonnego kręgowców wykonane przez Henryka Hoyera (1864-1947). Prelekcje o charakterze ogólnym mają na celu zapoznanie z miejscem, jego historią, zasobem i problematyką opracowania archiwów osobistych. Istnieje również możliwość zorganizowania pokazów

19 Jerzy Wyrozumski, Przedmowa, [w:] Odłamki pamięci o Wielkiej Wojnie. Tym, którym cześć i miłość winniśmy w darze, Kraków 2014, s. 3.

${ }^{20}$ Zob. Niepodległej... 100. rocznica odzyskania niepodległości 1918-2018, red. Adam Górski, Kraków 2018. 
tematycznych poświęconych badaczom konkretnej dyscypliny czy fotografii jako źródle dla historii nauki i kultury. Obecnie przechowujemy ponad 280 zespołów pochodzenia prywatnego, co czyni z tego miejsca prawdziwy skarbiec pamięci.

Archiwum Nauki wykorzystuje również do promocji swoich zbiorów bazę Spuścizna, której celem jest scalenie informacji o zespołach prywatnych przechowywanych w krakowskich archiwach, bibliotekach i muzeach oraz udostępnienie jej w jednolitej formie. Cennym projektem jest również „PAUart. Katalog online zbiorów artystycznych i naukowych Polskiej Akademii Umiejętności”. W latach 2014-2017 opracowano naukowo i udostępniono na jego stronie 5000 fotografii ze spuścizn: historyków sztuki Karoliny Lanckorońskiej (1898-2002) oraz Lecha Kalinowskiego (1920-2004), filozofa Wincentego Lutosławskiego (1863-1954), geologa Walerego Goetla (1889-1972) i fizyka Władysława Natansona (1864-1937). W 2018 r. założono i na bieżąco aktualizowano profil na Facebooku. Zamieszczono 168 postów, a liczba osób śledzących stale rośnie. Ponadto, już wkrótce zasób będzie można znaleźć na platformie szukajwarchiwach.pl.

Wymieniając inne inicjatywy mające na celu popularyzację źródeł historycznych i dotarcie do możliwie szerokiego grona odbiorców, warto zaznaczyć, że Archiwum Nauki wzięło udział w zdjęciach do filmu poświęconego PAU, udostępniło materiały do produkcji o Walerym Goetlu, Wacławie Felczaku, a także dokumentu zrealizowanego przez Unisławskie Towarzystwo Historyczne oraz młodzież z Koła filmowego Liceum Ogólnokształcącego w Unisławiu Króliki z Ravensbrück, powstałego na podstawie relacji więźniarek, w tym Wspomnień wojennych Karoliny Lanckorońskiej. Wychodząc naprzeciw najmłodszym - 20 marca 2018 r. gościło uczestników konkursu „Plus ratio quam vis. Służąc Ojczyźnie - pracą, myślą, talentem”, organizowanego przez Akademię Żakowską w Krakowie, Muzeum UJ Collegium Maius oraz Stowarzyszenie Szersze Horyzonty. Celem konkursu jest propagowanie miejsc związanych ze środowiskiem naukowo-artystycznym Krakowa oraz dorobku uczonych i twórców kultury. Z kolei 9 września 2018 r. w archiwalnych murach zatrzymali się uczestnicy III Biegu Pocztyliona „Królewska Poczta Polowa, Wolność" - bieg z pogranicza kultur Wielkim Gościńcem Litewskim oraz śladem Szlaku Jagiellońskiego „Słowiańskie Korzenie”, którzy mieli okazję obejrzeć wspomnianą wystawę „Orient bliski i daleki”.

Archiwum przy ul. św. Jana 26 jako miejsce otwarte na współpracę od lat nawiązuje liczne kontakty krajowe i zagraniczne na niwie naukowej, przekładające się na promocję zasobu oraz popularyzację nauki. Zbiory użyczane są do wystaw w innych instytucjach ${ }^{21}$, a ich kopie do projektów badawczych W ramach porozumienia z Instytutem Filozofii UJ udostępniono materiały archiwalne ze spuścizny Romana Ingardena (1893-1970) na potrzeby realizowanego tam grantu „Archiwum Elektroniczne Romana Ingardena. Nieznana korespondencja i prace naukowe wybitnego polskiego humanisty”. Przedstawiciele archiwum wzięli również udział w warsztatach towarzyszących konferencji „Roman Ingarden

${ }^{21}$ Np.: „Walczące miasto”, Muzeum Historyczne Miasta Krakowa (16 września 2015 - 21 lutego 2016 r.); „Pod przewodnią gwiazdą nauki. W stulecie śmierci Mariana Smoluchowskiego”, Muzeum UJ Collegium Maius (3 września - 15 października 2017 r.); „Pamięci prof. Aleksandra Birkenmajera 1890-1967”, Biblioteka Jagiellońska (14 października - 15 listopada 2017 r.); „Henryk Niewodniczański krakowski fizyk z Wiednia”, Instytut Fizyki UJ (13 grudnia 2018 - 31 stycznia 2019 r.). 
and His Times. An International Phenomenologigal Conference 2018" (26 października 2018 r.).

W identyfikacji oraz opracowaniu materiałów często nieodzowna jest pomoc specjalistów, która staje się jednocześnie punktem wyjścia do wspólnych projektów i przedsięwzięć. Długoletnią tradycję ma już współpraca z orientalistami warszawskimi, a za ich pośrednictwem z innymi ośrodkami naukowymi. Obecnie trwają rozmowy z Wydziałem Historii i Archeologii Mongolskiej Akademii Nauk oraz Zakładem Turkologii i Ludów Azji Środkowej Wydziału Orientalistyki Uniwersytetu Warszawskiego w sprawie publikacji materiałów dotyczących spisu powszechnego w Mongolii w latach 1915-1916 ze spuścizny Władysława Kotwicza (1872-1944). W 2017 r. Archiwum Nauki na zaproszenie strony japońskiej wzięło udział w konferencji naukowej „The I Workshop for International Cooperative Project »Analyzing Historic Photographs of Foreign Missionaries and Expeditions to Mongolia«", zorganizowanej przez National Museum of Ethnology w Osace (7-8 listopada), na której prezentując bazę danych PAUart, omawiano możliwości współpracy w oparciu o zbiór fotografii z wymienionego wyżej zespołu ${ }^{22}$. Tego typu cenne inicjatywy sprawiają, że spuścizny „ciągle żyją”, a ich twórcy nadal pozostają ambasadorami polskiej nauki w świecie.

Od 2003 r. utrzymywana jest współpraca z Instytutem Masaryka i Archiwum Akademii Nauk Republiki Czeskiej. Piętnaście lat wspólnych przedsięwzięć wydawniczych, konferencji i wystaw było również okazją do wymiany doświadczeń w zakresie metodyki archiwalnej. Zwłaszcza że zagadnienia związane z opracowaniem spuścizn, terminologia, problem sprecyzowania granic zespołu stanowią ciągle przedmiot żywej dyskusji ${ }^{23}$. W latach 2016-2018 współdziałano w ramach projektu badawczego pt. „Wymiana inspiracji i wiedzy w kontaktach czeskich i polskich uczonych”. W 2017 r. ukazała się trójjęzyczna (polsko-czesko-angielska) edycja źródłowa korespondencji prawników Adama Vetulaniego i Miroslava Boháčka ${ }^{24}$. Trwają prace nad innym wydawnictwem źródłowym - edycją listów Walerego Goetla i Radima Kettnera. Na lata 2019-2021 przygotowano kolejny projekt pt. „Rekonstrukcja kontaktów naukowych i stosunków transnarodowych między czeskimi i polskimi uczonymi w XIX i XX wieku”. Wszystkie wymienione przedsięwzięcia pokazują, jak ważne jest budowanie świadomości i kultury naukowej nie tylko w wymiarze społecznym, ale i międzynarodowym. Ścisła współpraca instytucji to najlepsza droga do upowszechniania osiągnięć nauki.

Archiwum Nauki, prowadząc zróżnicowaną, wielopłaszczyznową aktywność, nie rezygnuje z celu głównego: pozyskiwania, gromadzenia, opracowania i udostępniania spuścizn. Tym bardziej że dzięki bogactwu zbiorów miejsce to stanowi przede wszystkim: ,[...]

${ }^{22}$ Rita Majkowska, Stowo wstępne, [w:] E. Dziurzyńska, Orient bliski.., s. 4.

${ }^{23}$ Warto nadmienić, że jako pokłosie trzech konferencji zorganizowanych przez Archiwum Nauki PAN i PAU, tj. „Ocalone od niepamięci... Co kryją archiwa osobiste uczonych i twórców?” (22 czerwca 2012 r.); „Czas zatrzymany... Fotografie w spuściznach uczonych i twórców” (19-20 czerwca 2013 r.); „Ocean wszechrzeczy... w spuściznach ludzi nauki i kultury” (13 czerwca 2014 r.), ukazała się publikacja: Spuścizny - co po nas zostaje. Zagadnienia metodologiczne, red. Adam Górski, Kraków 2018.

${ }^{24}$ Korespondencja Adama Vetulaniego z Miroslavem Boháčkiem, oprac. Ewa Dziurzyńska, Martina Šumova, Kraków 2017. 
podstawową bazę dla badań w zakresie historii nauk, otwierając zarazem przed każdym badaczem perspektywę naukowoznawczej refleksji, budującej naukową kulturę o wymiarze interdyscyplinarnym" "25. Wszelkie zaś inicjatywy z zakresu popularyzacji zmierzają do tego, by pamięć o polskich uczonych żyła w kolejnych pokoleniach.

Paulina Krzywda Archiwum Nauki PAN i PAU w Krakowie

${ }^{25}$ Jerzy Wyrozumski, Slowo wstępne, [w:] M. Mrówka, M. Maciuk, Ocalone od niepamięci..., s. 6. 